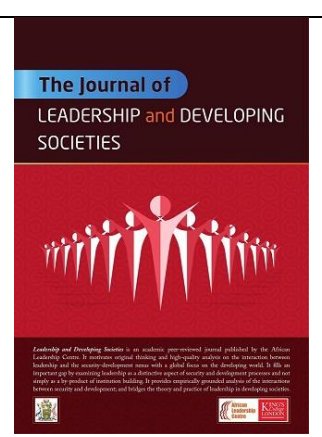

ARTICLE

\title{
The Battle for Guatemala: Multilevel Governance and the Nation-state
}

Gloriana Rodriguez Alvarez

Available online 23 December 2020

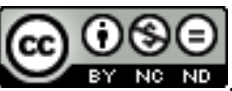

\begin{abstract}
Although a brutal Civil War ended in 1996 and a democratisation process was initiated, Guatemalan statehood remains contested. Due to a historical process defined by elite capture and extreme repression, the State never fully consolidated. As a result, formal institutions tasked with political and economic governance are not as robust or effective as the informal institutions. There have been important developments. For instance, a myriad of social actors was able to carve out a space of public political and economic resistance which continues to this day. Notwithstanding these advances, Guatemala is now facing widespread insecurity as a result of the rise of transnational drug-trafficking, and the presence of gangs and cartels. The current crisis has worsened historic and structural injustices. In this regard, security governance is never an isolated issue. It is deeply interwoven with political and economic forms of governance. Due to the weak political governance, cartels and gangs can operate with near impunity. Then, because of weak economic governance, there are countless desperately poor youths willing to enter the drug trade. To address these security issues, it is crucial to look at the institutional, political and social factors which have shaped the national context.
\end{abstract}

Keywords: multi-level governance; Guatemala; state capture; democratisation; leadership

\section{INTRODUCTION}

Guatemala is currently in the midst of a regional insecurity crisis as a result of transnational drug trafficking, increasing crime and the presence of gangs and cartels. ${ }^{1}$ These security dilemmas have aggravated pre-existing and structural issues related to poverty, institutional weaknesses, and impunity. ${ }^{2}$ In this regard, security governance is never an isolated issue. It is deeply interwoven with political and economic forms of governance. For this reason, to address these new security challenges, it is crucial to look at the underlying institutional, political and social paradigm of Guatemala

\footnotetext{
a Gloriana Rodriguez Alvarez's is a PhD candidate in Leadership Studies with reference Security and Development, at the African Leadership Centre, King's College London.

Email: gloriana.rodriguez_alvarez@kcl.ac.uk

${ }^{1}$ Crisis Group Latin America (2011), ‘Guatemala: Drug Trafficking and Violence’, Report N³9, pp. 1. Available at: https:/ / d2071andvip0wj.cloudfront.net/39-guatemala-drug-trafficking-and-violence.pdf [accessed 14 April 2020]

2 Schultze-Kraft, Markus, Chinchilla, Fernandez, and Moriconi, Marcelo (2018), 'New perspectives on crime, violence and insecurity in Latin America', Crime Law Social Change 69, pp. 465-473
} 
Guatemalan democracy is relatively young. In 1996, a thirty-six-year Civil War ended, which has been described as one of the most brutal conflicts in Latin America. ${ }^{3}$ Guerrillas, labour union activists and political dissidents were tortured, disappeared, and even publicly executed during the war. In the 1980s, the Mayan people were subjected to a genocide. According to the Commission for Historical Clarification, 200,000 individuals were killed and 40,000 disappeared. It is estimated that $83 \%$ of those killed were indigenous peoples. ${ }^{4}$

During the war, the country was governed by a series of military dictatorships, whose rule undermined civilian political and economic institutions of governance. In order to end the war and establish and strengthen democratic institutions, the Peace Accords, 'Agreement on a Firm and Lasting Peace', were signed between the guerrillas under the umbrella of Unidad Revolucionaria Nacional Guatemalteca (URNG) and the government.

Despite the collective efforts to enshrine a new political order, emerging security threats have completely changed the social psyche. There is a correlation between the increasing violence and increasing support for authoritarian policies. Once again, insecurity is the "central theme of politics in the region." 5 This has had the effect of eroding the democratic gains from the late 1990s.

It should be noted that institutions of formal governance are those which are "established in law"; whereas the institutions of informal governance are those which are "not established in law." 6 In Guatemala, although the armed conflict officially ended and a democratisation process was initiated, Guatemalan statehood remains contested. The historical antecedents combined with new threats, like transnational crime, have made it difficult for the State to fully consolidate. As a result, formal institutions tasked with political and economic governance are not as robust or effective as the

\footnotetext{
3 Briscoe, Ivan (2009), 'A Criminal Bargain: The State and Security in Guatemala', Fundación Para Las Relaciones Internacionales Y El Diálogo Exterior (FRIDE). Madrid, 2009. V24

${ }^{4}$ Historical Clarification Commission (CEH) (1999), Guatemala: Memory of silence. Guatemala City: Historical Clarification Commission, p. 17

${ }^{5}$ Krause, Krystin (2016), 'The News Media and Public Support for Repressive Crime Control in Guatemala',
}

informal institutions. In this sense, governance is informal.

To this end, this paper will examine why Guatemalan statehood remains contested by examining the relationship between formal and informal institutions of governance. The paper draws from a framework based on democratisation and institutional change to examine the factors which have defined formal and informal governance. To this end, it will identify the myriad of actors which have contributed to the rise of certain institutions of political and economic governance. Furthermore, it will explore how and why the formal institutions of governance do not have the same degree of legitimacy or strength as informal institutions.

\section{GUATEMALA'S SECURITY UNIVERSE}

Below is an overview of the current security universe of Guatemala. It reveals the complex and intersecting relationship between informal and formal actors of governance:

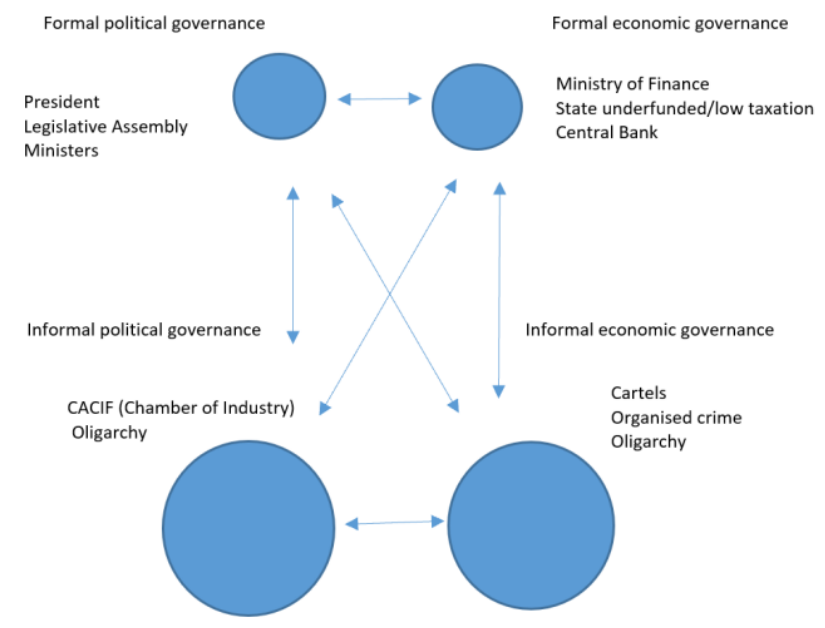

2.1. Political Governance

Panoramas Scholarly Platform. Available at: https://www.panoramas.pitt.edu/news-and-politics/newsmedia-and-public-support-repressive-crime-controlguatemala [accessed 17 April 2020]

${ }^{6}$ Rye, Tom, et al. (2018), The relationship between formal and informal institutions for governance of public transport, Journal of Transport Geography, Volume 69, pp.196-206

https://doi.org/10.1016/j.jtrangeo.2018.04.025 
In Weberian terms, a state is defined as "a political body, which successfully claims the monopoly over the legitimate use of the means of violence in a given territory."7 In this regard, statehood is tied to security. This view has been complemented by the notion that statehood should also encompass the rule of law and "infrastructural power" ${ }^{8}$ In other words, the capacity to tax and provide public services. ${ }^{9}$ Nonetheless, in Guatemala, the efforts to consolidate a state which satisfies these criteria have always been undermined by the most powerful social actors. During the colonial era this included wealthy landowners. Overtime, it has also come to include businessmen and even violent non-state actors. ${ }^{10}$

\subsubsection{A captured colonial state}

Historically, the regimes in control of the Guatemalan territory have relied on repression. The process of colonisation, beginning in the $16^{\text {th }}$ Century, was rooted in the extreme political and economic exploitation of the indigenous peoples. ${ }^{11}$ This was justified by a racist discourse which deemed indigenous peoples 'subhuman'.12 Over time, the social, political and economic model of the colonial administrative apparatus also led to the rise of a powerful elite of Spanish ancestry. In turn, this elite used the administrative apparatus to promote their private

\footnotetext{
7 Weber, Max (1919), Politik als Beruf, München und Leipzig. Verlag von Duncker \& Humblot, p.4

8 Pearce, Jenny (2018), 'Elites and Violence in Latin America Logics of the Fragmented Security State', Violence, Security, and Peace Working Papers. Available at:

http://www.lse.ac.uk/lacc/publications/PDFs/VSP1-

Pearce-Elites-Violence-Latin-America-web.pdf [accessed 14 April 2020]

${ }_{9}^{9}$ Mann, M. (1986), 'The Autonomous Power of the State', In: Hall, J.A. (ed.) States in History (Oxford: Blackwell) pp.109-136 10 Pearce, Jenny (2018), p.15

${ }^{11}$ CICIG (2019), Guatemala: un Estado capturado, pp. 21.

Available at: https://www.cicig.org/wpcontent/uploads/2019/08/Informe_Captura_Estado_2019.p df [accessed 2 April 2020].

12 Casáus Arzú, Marta (2018), 'El racismo y su proyección actual: ¿un fenómeno nuevo o un problema sin resolver?', Cuadernos de Trabajo Social, 31(1), p.121

13 Arévalo, Bernardo (2013), Estado violento y ejército político: formación estatal y función militar en Guatemala (1524- 1963) (Guatemala: FyG Editores), p. 96
}

commercial interests. ${ }^{13}$ That dynamic remains intact: the premise of the colonial order has become the premise of the postcolonial state. ${ }^{14}$

For this reason, the contemporary Guatemalan state has been described as a 'captured state'. ${ }^{15}$ There is a small elite which has deep familial ties and shared economic interests. Rather than governing for the common good, the State continues to respond to their needs. ${ }^{16}$ Additionally, the underlying racist discourse which justified the exclusion of indigenous peoples has not been rejected. It has merely mutated, whilst remaining firmly entrenched in the social imaginary. ${ }^{17}$ Indeed, the vast majority of the elite do not believe they "share a common destiny with the subaltern members of society". 18

Even after two decades of democratisation, the institutional underpinnings of elite capture linger. ${ }^{19}$ The elite are deeply invested in maintaining the status quo and thus are willing to undercut the attempts to establish the rule of law. ${ }^{20}$ To this end, there are entrenched "elite networks" which use "money, means of force, information, and ideas and ideologies" to further their interests. ${ }^{21}$

As a result, access to justice and rule of law are not universally guaranteed. To the contrary, these are mere instruments which are wielded and manipulated by a small, privileged elite. ${ }^{22}$ Furthermore, the state lacks an independent and professionalised bureaucracy. Job opportunities are not based on pre-established qualifications and institutions are not fully

14 Casáus Arzú, Marta (2018), p. 128

15 CICIG (2019), p.9

16 Ibid. p.10

${ }^{17}$ Casáus Arzú, Marta (2018), p. 135

18 Sanchez, Omar (2009), 'Tax Reform Paralysis in PostConflict Guatemala,' New Political Economy, 14:1, pp. 101-131

${ }^{19}$ Gútierrez, Edgar (2016), Guatemala elites and organized crime, Insight Crime, Available at:

https://www.insightcrime.org/wpcontent/uploads/2018/02/Guatemala_Elites_Organized_Cri me [accessed 6 April 2020]

20 Dudley, Steven (2018), 'Public security in private hands: the case of Guatemala's Carlos Vielman', Crime Law and Social Change 69, pp. 519-531. Also; Holden, Robert (2004), Armies without Nations: Public Violence and State Formation in Central America 1821-1960 (Oxford: Oxford University Press) 21 Bull, Benedicte (2014), 'Towards a Political Economy of Weak Institutions and Strong Elites', European Review of Latin American and Caribbean Studies, 97, p. 122

22 Pearce, Jenny (2018), p. 11-12 
autonomous. ${ }^{23}$ Lastly, the formal means of governance have to override informal governance. ${ }^{24}$ Since the Guatemalan state does not satisfy the abovementioned criteria, "democratisation cannot be equated with a commitment to the Weberian state" ${ }^{25}$

Given these antecedents, there is a debate regarding the nature of the Guatemalan state. Some authors have agreed that Guatemala epitomizes a 'captured state'. ${ }^{26} \mathrm{In}$ contrast, others consider that Guatemala transcends the concept of state capture. The concept originally referred to states which cater to the interests of specific groups. However, it does not contemplate the presence of illegal groups which employ coercion and violence as opposed to bribery to influence the State. ${ }^{27}$ Besides the oligarchic elite, informal governance is also shaped by the rise of organised criminal groups. ${ }^{28}$

\subsubsection{Informal Leviathan}

Due to the weakness of formal governance, the Guatemalan state has been described as simultaneously fragile and repressive. ${ }^{29}$ It should be noted, there is no single definition for what constitutes state fragility. States are deemed fragile when there is an 'institutional deficit', meaning that the state is unable to provide public services and goods. This could be due to a lack of resources, a lack of infrastructure, or because of corruption which undermines their effectiveness. ${ }^{30}$ The Guatemalan state is considered fragile because it has lacked authority, power and legitimacy. Another characteristic used to assess state fragility is a lack of 'economic welfare', when there is widespread poverty or extreme social inequality. Closely linked to this, is the issue of a 'social deficit': a lack of social cohesion. ${ }^{31}$ Due

\footnotetext{
23 Sanchez, Omar (2009), p. 110

24 Bachmann, Olaf. 'Who Guards the Guardian: Seminar on the State, State Institutions and Governance of Security', Lecture, King's College London, 8, February 2018

25 Pearce, Jenny (2018), p.13

26 Sanchez, Omar (2009), p.113

27 CICIG (2019), p.12

28 Bull, Benedicte, Castellacci, Kashara, Yuri (2014), Business Groups and Transnational Capitalism in Central America: Economic and Political Strategies (New, York: Palgrave Macmillan), p.185

${ }^{29}$ Holden, Robert (2004), Armies without Nations: Public Violence and State Formation in Central America 1821-1960 (Oxford: Oxford University Press), p. 130

30 Albertson, Andrew and Moran, Ashely (2017), Untangling the Complexity of Fragile States. Available at:
}

to the abovementioned characteristics, the state is often unable to exert control over the territory. Criminal networks and other violent non-state actors are more likely to flourish and erode state legitimacy further. ${ }^{32}$

The Guatemalan state meets the criteria for fragility. There is an institutional deficit, a lack of economic welfare and a social deficit. Moreover, the state lacks robust formal institutions of governance. Indeed, the legitimacy of modern political parties, the civil justice system and legislature are all contested. According to opinion polls, there is greater trust in the army and the Catholic Church..$^{33}$ Due to institutional weakness, it has relied on a volatile alliance between state and non-state actors, based on coercion and violence. ${ }^{34}$ This has made informal governance have a much greater role in the national tapestry. Consequently, the state has had to rely on repression as well.

Throughout history, Guatemala was governed by a "mythically powerful central figure" who would then delegate power to regional military leaders and militias. ${ }^{35}$ This has inadvertently given the military a degree of protagonism within the political leadership. It has often considered itself the "guarantor of the state and defender of the existing social order". The colonial administration depended on an army and unofficial militias established to subjugate the indigenous peoples. This was challenging given that from the very beginning there was a resistance. The indigenous peoples rioted every week. In response, the repression became even more severe. Over time, the formal and informal security apparatus became akin to a "prison with a municipal regime" for the more than 700 indigenous peoples. ${ }^{36}$

\section{http://trumancenter.org/wp-} content/uploads/2017/03/Untangling-the-Complexity-ofFragile-States.pdf [accessed 4 November 2020].

${ }^{31}$ Ibid

32 Michel, James (2018), 'Managing Fragility and Promoting Resilience to Advance Peace, Security, and Sustainable Development' pp. 4-11, Center for Strategic and International Studies (CSIS). doi:10.2307/resrep22409. [accessed 4 November 2020] ${ }^{33}$ Sanchez-Ancochea, D. (Ed.), Martí i Puig, S. (Ed.). (2014), Handbook of Central American Governance. London: Routledge, p149-163

34 James (2018), p. 26

$35 \mathrm{Ibid}, \mathrm{p} .28$

${ }^{36}$ Figueroroa Ibarra, Carlos (2011) El recurso del miedo. Estado y terror en Guatemala. F\&G Editores: Guatemala City, pp.93-96 
In the aftermath of Independence in 1821, Guatemala continued to be governed by military leaders, determined to protect the interests of the oligarchy. ${ }^{37}$ Thus, the dictatorships "perpetuated colonial social formation despite independence." 38 Throughout this period, there was a persistent, heterogeneous resistance. In 1917, the opposition against the Dictator Cabrera included a broad coalition of students, urban workers and small-business owners. ${ }^{39}$ Then, in 1944, the Dictator Ubico was also opposed by students, academics, professionals and low-ranking army officers. They aimed to establish a true democracy. ${ }^{40}$ Yet, even when it has lacked a political mandate, the military has had no qualms about overruling the popular sentiment, persecuting the opposition and installing military rulers. ${ }^{41}$ Hence, the twentieth century can be defined by the term, "political authoritarianism". ${ }^{42}$

Rather than developing robust institutions and governing by consensus, the state has remained dependent on repressive social actors. In the case of Guatemala, "it is control, not legitimacy, which has cemented social and political relations." 43 The Guatemalan state evolved into an informal Leviathan. The state tries to control the national territory through sheer repression. Ultimately, it fails. Instead of monopolising violence, it has merely provided a framework to be usurped by more powerful social actors. This includes the ethnic elite, the military elite and the emerging criminal groups.

In the case of Guatemala, the formal institutions of governance, such as the Legislative Assembly are not as powerful as the informal institutions of governance, such as the oligarchy run businesses. The process of

\footnotetext{
37 Meade, Teresa A (2009), A History of Modern Latin America: 1800 to the Present. Chicester: John Wiley \& Sons

38 Figueroroa (2011), p. 88

39 Kit, Wade (1990), 'The fall of Guatemalan dictator, Manuel Estrada Cabrera: US Pressure or national opposition?' Canadian Journal of Latin American and Caribbean Studies / Revue Canadienne Des études Latino-américaines Et Caraibes 15, no. 29 (1990), pp. 105-27

40 Streeter, Stephen (2000), Managing the Counterrevolution: The United States and Guatemala, 1954-1961. Athens: Center for international studies, p. 12

41 Alvarez, Enrique and Palencia Prado, Tania (2011),

'Guatemala's peace process: context, analysis and evaluation', In: Barnes, Catherine (eds.) Owning the Process. Public Participation in peace-making (London: Conciliation Resources) p. 39

42 Sandoval, Francisco (2003), Encanto y desencanto con la

Democracia. Librerías Artemis Edinter: Guatemala
}

democratisation has not "eradicated" these deep-seated tendencies. ${ }^{44}$ In order to understand the dichotomy between state fragility and repression, it is essential to look at the underlying historical process that has led to present conditions. Domination and exploitation have been the defining features of the historical processes during the last few centuries. Colonial violence, from 1524-1821,45 destroyed the social fabric and instead became the premise of the social order. Throughout the postcolonial era (1821-the present), violence has been wielded by both formal institutions and by informal social actors. ${ }^{46}$ To make matters worse, impunity became even more entrenched during the Civil War. For three decades, there were widespread human rights abuses and violations. Often committed directly by state actors and paramilitaries whilst implementing state policy. ${ }^{47}$ In place of rule of law, violence and impunity became central to the institutional paradigm.

Even after two decades of democratisation, from 1996 to the present, the damage has not been undone. Human rights activists have argued that justice is still determined by "plata o plomo" - silver or lead. Furthermore, although there are many types of criminality, the consensus is that it flourished because of the "weakness of the state". 48

The weakness of formal governance is then exploited by the oligarchic private sector and emerging criminal groups. For the business elites, it means setting the political agenda. This is achieved by filling public institutions and regulatory agencies with the bureaucrats of their choice. ${ }^{49}$ They have even managed to determine key positions in the high courts. ${ }^{50}$ Then, once they are in positions, these networks advance their

\footnotetext{
43 Sanchez, Omar (2009), p. 110

${ }^{4}$ Cruz, J.M. (2016), 'The State and the Reproduction of Violence in Post-Transition El Salvador and Guatemala', In: Ruzza, S., Jakobi, A., and Geisler, C. (eds.) Non-State Challenges in a Re-ordered World: The Jackals of Westphalia (London: Routledge) p. 136

45 Webre, Stephen (2019), 'Guatemala (Colonial Period)'. Oxford Bibliographies in Latin American Studies. Available at: doi:10.1093/obo/9780199766581-0209 46Pearce (2018), p.13

47 Palencia Prado, T. (1997), 'Advocates \& Guarantors: Establishing participative Democracy in Post War Guatemala', In: Sieder, R. and Wilson, R (eds.) Negotiating Rights (London: Conciliation Resources), p. 14

48 Crisis Group Latin America (2011), p.6

49 Dudley (2018), p. 521

50 Gútierrez (2016), p.9
} 
agenda by paying financial bonuses, dubbed "dobletes", to ministers and other state employees who agree to go from the private to the public sector. ${ }^{51}$ They have also pushed their interests by financing electoral campaigns, in a quid pro quo, which then gives them undue influence over elected officials. ${ }^{52}$

To have a more direct influence, the elites have relied on lobbying by the CACIF, the Coordinating Committee of Agricultural, Commercial, Industrial, and Financial Associations. From its very beginning, the CACIF has adhered to a conservative ideology. Its focus has been on defending and preserving the status quo..$^{53}$ For this reason, this organization is considered the "de facto political party of Guatemala's economic elites". ${ }^{54}$ In some ways, it is more powerful than political parties in Congress. Indeed, the extent of their relationships with CACIF was the best predictor of each congressman's voting behaviour. Even more so than actual party affiliation. ${ }^{55}$

The result of the direct and indirect elite influence is the development of an institutional apparatus which caters specifically to elite needs. By law, the Chamber of Business has representation in fifty-eight different state organs. ${ }^{56}$ Business elites have disproportionate influence in public policy formulation throughout Latin America, "but nowhere more than Guatemala." 57

When those techniques do not have the desired outcome, there have even been extrajudicial measures. 58 There have been cases of judicial intimidation and the bribery and corruption of lawmakers. ${ }^{59}$ The use of coercion and extrajudicial means in order to deal with conflict also applies to intra-elite relationships. Within Latin America, Guatemala has the "highest incidence of intra-elite violence." 60 Whereas much of Guatemalan society is concerned by the increasing violence and

\footnotetext{
51 Ibid, p.8

52 Ibid, p.84

53 Sanchez, Omar (2009), p. 108
}

${ }^{54}$ Gútierrez, Edgar (2016), p. 8

55 Bull, Castellacci, Yuri (2014), p.184

56 Rodríguez Quiroa, Luisa Fernanda (2018), 'Empresarios con poder: al menos 58 instancias del Estado en las que las cámaras tienen voto o voz', Plaza Pública. Available at: https://www.plazapublica.com.gt/content/empresarioscon-poder-58-instancias-del-estado-en-las-que-las- camarastienen-voz-y-voto [accessed 17 April 2020].

57 IDB (2006), The Politics of Policies. Economic and Social Progress in Latin America, 2006 Report. Inter-American Development Bank, p. 98. Available at: insecurity; it is a mere inconvenience for the oligarchic elites. They have the option of living in gated communities and can afford to pay for private security. ${ }^{61}$ As such, insecurity is only an issue when it directly threatens their power, their profit or their well-being. ${ }^{62}$

Despite the many hurdles, one positive development has been a political resistance via the rise of civil society. These organisations work with the formal institutions of political governance to strengthen rule of law and human rights protection. It should be noted that during the Civil War, labour unions, indigenous social movements, women's groups, and other grassroots organisations faced varying levels of persecution. For decades, the political resistance had to go underground to merely survive. ${ }^{63}$ By the time the Peace Accords negotiations were initiated, in the late eighties, the political resistance had splintered. Little by little, they participated under the umbrella organisation, the ASC (Civil Society Assembly (ASC). Ultimately, the process revitalised civil resistance and led to the "institutionalisation of organisations in civil society." 64 As such, they were able to carve out a space of public political resistance which continues to this day.

Notwithstanding the advances made regarding civic participation and social contestation, the state is still fragile. It is not formal institutions of political governance, but rather informal institutions of political governance which shape the political landscape. Thus, it is a state which now has spaces for dissent, but which continues to cater to the elites.

The informal institutions of governance remain the most powerful actors within the national theatre. Certain informal institutions of governance, such as the CACIF, carry more weight than the formal institutions of governance, such as the Legislative Assembly when it

https://publications.iadb.org/en/publication/16950/politics -policies-economic-and-social-progress-latin-america-2006report [accessed 21 April 2020]

58 Dudley, Steven (2018), p. 521

${ }^{59} \mathrm{Ibid}, \mathrm{pp} .521$ and 530

60 Pearce, Jenny (2018), p. 22

${ }^{61} \mathrm{Ibid}, \mathrm{p} .19$

62 Dudley, Steven (2018), p. 522

${ }^{63}$ Brett, R. (2017). The Role of Civil Society Actors in Peacemaking: The Case of Guatemala. Journal of Peacebuilding \& Development, 12(1), 49-64.

https://doi.org/10.1080/15423166.2017.1281756

${ }^{64}$ Krznaric, R. (1999). Civil and Uncivil Actors in the Guatemalan Peace Process. Bulletin of Latin American Research, 18(1), 1-16. Retrieved November 5, 2020, from http://www.jstor.org/stable/3339471 
comes to policymaking. In this regard, the Guatemalan context provides another dimension to the discussion regarding state legitimacy and capacity. Due to the state fragility, the informal actors of political governance can override the formal democratic political institutions. This dynamic is not limited to the formal and informal actors of political governance. It permeates the relationship between formal and informal actors of economic governance as well.

\subsection{Economic governance}

Formal political governance is deeply tied to formal economic governance. It should be noted economic governance refers to the formal and informal actors which "support economic activity and economic transactions by protecting property rights, enforcing contracts." ${ }^{65}$ Much like political governance, another of the "colonial legacies is the concentration of excessive power in the economic elites." 66 The indigenous peoples have been subjected to centuries of political and economic exclusion. ${ }^{67}$ One of the long-term consequences of their widespread exclusion is the consolidation of an economic and political elite, determined to protect its privileges. Subsequently, economic governance is not driven by the common interest. Above all, it responds to elite whims.

\subsubsection{The money gap}

Due to the historic and contemporary dominance of the oligarchy, the Guatemalan state has been driven by private interests. Beginning in the second half of the twentieth century until now, the Chamber of Commerce and corporate groups have influenced the naming of key positions within the Ministry of Finance and Economics, the Central Bank, the Monetary Board and the Superintendence of Banks. ${ }^{68}$

65 Dixit A.K. (2008), 'Economic Governance'. In: Palgrave Macmillan (eds) The New Palgrave Dictionary of Economics. Palgrave Macmillan, London. https://doi.org/10.1057/978-1349-95121-5_2611-1

66 CICIG (2019), p. 21

67 Marc Becker (2008), 'Third Continental Summit of Indigenous Peoples and Nationalities of Abya Yala: From Resistance to Power', Latin American and Caribbean Ethnic Studies, 3:1, 85-107, DOI: 10.1080/17442220701865879

68 Ibid p.10

${ }^{69}$ Bull, Benedicte, Castellacci, Kashara, Yuri (2014), p. 184
It has been alleged that the business sector has "veto powers" when it comes to public policy formation. ${ }^{69}$ The business sector is very powerful because the oligarchs own the majority of the domestic capital investment. ${ }^{70}$ Also, because it is arguably the best-organised sector. Since the colonial period, the commerce sector has had the time to grow and strengthen, in stark contrast to other social sectors and public institutions. Indigenous movements, labour unions, civil society organisations and academics have all endured periods of persecution and oppression. This has all undercut their capacity to influence policymaking. ${ }^{71}$

Despite their dominance, the business elites are far from being a monolithic unit. They are a heterogeneous group with diverse and sometimes conflicting aims. The most prominent rifts are between the emerging sectors and the traditional land-owning sector. ${ }^{72}$ Despite this, they are successful at pushing their agenda for two reasons. Firstly, they have common political and business interests. Their cohesion is essentially limited to vetoing any initiative which is perceived to undermine their interest. This leads them to vehemently oppose the very measures which are required to finance state institutions and social programs. For example, they prevent tax policy reform, strengthening the public sector, and social assistance programs..$^{73}$

Secondly, the elite agenda is also easier to promote and implement because of a weak opposition..$^{74}$ The thirty-six-year civil war (1960-1996), was defined by brutal repression against anyone who dared question the military dictatorships. Labour union members, Catholic grassroots activists, intellectuals and Marxist students were murdered or disappeared. To this day, the 'popular sectors', the social groups which include both the working class and the political parties and civil society organizations which advocate for the working

\footnotetext{
70 Sanchez, Omar (2009), p. 111

71 IDB (2006), p. 98

72 Sanchez, Omar (2009), p. 109

${ }^{73}$ Cabrera, Maynor and Schneider, Aaron (2013),

'Instituciones, Impuestos, y Desigualdad en Guatemala',

Woodrow Wilson Center for the Americas, Available at:

https://www.wilsoncenter.org/sites/default/files/media/d ocuments/publication/Guatemala\%20V2.pdf [accessed 14

April 2020]

${ }^{74} \mathrm{Ibid}, \mathrm{p} .3$
} 
class, ${ }^{75}$ remain fragmented and weak. ${ }^{76}$ Unlike the rise of civil society organisations which advocate for human rights, the organisations and political parties which advocate for economic structural reform have not had the same levels of success. For this reason, Guatemala has been dubbed the "paradise of the ideological right". 77 Subsequently, there is a complete lack of "regulatory capacity over the private sector, both in terms of security and social policies". ${ }^{78}$ In many ways, business elites follow their whims without much government oversight.

Concretely, this dynamic has also led to a very feeble taxation system despite the many efforts made to reform it. ${ }^{79}$ Guatemala has the lowest taxation in Central America and one of the most limited state resources in Latin America. ${ }^{80}$ The wealthier citizens pay low tax rates, even though it means the state is unable to provide basic public services. ${ }^{81}$ Over the course of the last four decades, there have been several attempts to reform the tax system. Nevertheless, the elites have managed to prevent any profound reforms. ${ }^{82}$

In 1986, the Cerezo administration attempted to reform the tax rate from $7 \%$ to $8.1 \%$. This measure was unanimously rejected by the private sector, which proceeded to launch a media offensive. Then, the CACIF met with the members of the National Constituent Assembly. Due to their pressure, the Minister of Public Finance was asked to step down. Afterwards, four of the tax decrees were repealed. ${ }^{83}$

Afterwards, in 1996, another attempt was made to reform the tax law. It is worth noting that the Peace

\footnotetext{
75 Oxhorn, Philip (1990), 'The Popular Sector Response to an Authoritarian Regime: Shantytown Organizations Since the Military Coup'. Latin American Perspectives, vol. 18, no. 1, 1991, pp. 66-91. JSTOR, www.jstor.org/stable/2633730.

76 Sanchez, Omar (2009), pp. 111-112

77 Torres-Rivas, Edelberto (2009), 'La difícil existencia de las izquierdas centroamericanas' A Contracorriente Revista de Historia Social y Literatura en América Latina. Vol. 6, Nº. 2, Winter 2009, pp. 17

78 Gútierrez, Edgar (2016), p. 11

79 Bull, Benedicte, Castellacci, Kashara, Yuri (2014), p. 184

80 Icefi (2015), Política fiscal: expresión del poder de las élites centroamericanas. Instituto Centroamericano de Estudios Fiscales (eds.) Aguilar Umaña, Isabel, p.26. Available at:

http://icefi.org/sites/default/files/politica_fiscal_expresion _del_poder_de_las_elites_centroamericanas.pdf [accessed 13 April 2020].

81 Crisis Group Latin America (2011), p. 21

${ }^{82}$ Cabrera, Maynor and Schneider, Aaron (2013), p. 20

83 Icefi (2015), pp. 30-31
}

Accords included a socioeconomic dimension. This was a response to the Civil War which was fuelled, in part, by extreme inequality with regards to land ownership, a lack of labour rights and poverty. ${ }^{84}$ Subsequently, "the centrepiece of the socioeconomic accords was taxation, given that it is the sine qua non for financing other reforms." 85 Concretely, the Peace Accords established fixed targets for increasing tax revenue. ${ }^{86}$ However, in the decades since Guatemala has not fulfilled these minimum requirements. 87

It has been estimated that to reduce poverty the government would need to increase spending in social programs and infrastructure to $15 \%$ of GDP. ${ }^{88}$ According to the World Bank, raising the Guatemalan state's income to finance basic public services and poverty reduction programs is the most important fiscal challenge. ${ }^{89}$ In effect, "the absence of a tax system has acutely limited the country's economic development potential." 90

The issue of taxation is key. From a historical perspective, western democratisation was inextricably tied to the rise of a modern taxation system. Huntington has argued that democratisation is not a fixed state but rather an ongoing process which ebbs and flows across the world. The first wave began in 1820-1926, as universal suffrage was established in certain countries. A second wave occurred when the Second World War ended. Then, from 1974 until the 1990s, almost thirty countries opted for democratisation. Central American countries were amongst them. ${ }^{91}$ When the third wave of democratisation began, the expectation was that it

${ }^{84}$ COHA (2011), 'Guatemala's Crippled Peace Process: A Look Back on the 1996 Peace Accords', Council on Hemispheric Affairs, Available at: http://www.coha.org/guatemalascrippled-peace-process-a-look-back-on-the-1996-peaceaccords/ [accessed 8 April 2020].

85 Sanchez, Omar (2009), p. 115

86 Ibid, pp. 114-115

87 Icefi (2015), p. 33

88 International Monetary Fund (2018), ‘Guatemala: More Investment and Social Spending Needed', Available at: https://www.imf.org/en/News/Articles/2018/05/30/NA0 60118-Guatemala-More-Investment-and-Social-Spending-

Needed [accessed 12 April 2020]

89 World Bank (2020), Guatemala Overview, Available at: https://www.worldbank.org/en/country/guatemala/overv iew [accessed 8 November 2020].

90 Sanchez, Omar (2009), p.102

91 Huntington, Samuel (1991), 'Democracy's Third Wave', Journal of Democracy 2(2), pp. 12-34 
would lead to more progressive tax policies. ${ }^{92}$ This was based on the assumption that the power base increases. Whereas in an autocracy the power base is restricted to a small group, in a democracy the power base should be more inclusive of the masses. ${ }^{93}$ Subsequently, the logic goes, the decision-making should be more favourable to the general interest. This has not happened in Guatemala, revealing "the shallowness of the country's democratisation." 94 The formal institutions of economic governance are incapable or unwilling to override the informal economic governance.

There have been few spaces of resistance against the informal and formal actors of economic governance. For example, there is the rise of indigenous protest movements, which seek to protect ancestral territories and natural resources. This includes activists from the Q'eqchi', Chuj, Q'anjob'al and Mam peoples who protest the hydroelectric projects in their ancestral homelands. There are also activists from the Xinka and Ch'orti' peoples who protest mining projects as well. ${ }^{95}$ In some cases, the projects are implemented in places where the formal institutions of governance are largely absent. As a result, the activists are contesting informal institutions of economic governance, such as transnational companies, but without support or protection from the State. ${ }^{96}$ In other cases, the indigenous activists are being persecuted directly by the state. The Special Reserve Public Security Squads (Escuadrones del Cuerpo Especial de Reserva para la Seguridad Ciudadana), is an army unit which has been deployed to 'pacify' indigenous territories. It should be noted that this is a violation of the Peace Accords of 1996, which stipulated the army could no longer be used in internal operations against citizens. ${ }^{97}$ By 2019,

\footnotetext{
92 Kato, J. and Tanaka, S. (2019), Does taxation lose its role in contemporary democratisation? State revenue production revisited in the third wave of democratisation, European Journal of Political Research, 58: pp. 184-208..

93 Sanchez, Omar (2009), p. 111

94 Ibid, p. 107

95 Oficina del Alto Comisionado de las Naciones Unidas (2019), Situación de las personas defensoras de derechos humanos en Guatemala: Entre el compromiso y la adversidad, pp.28-29.

Available at:

https://www.refworld.org.es/docid/5ce489654.html [accessed 9 November 2020]

96 Ibid., p. 2

97 IACHR (2015) Inter-American Commission on Human Rights Situation of Human Rights in Guatemala (OEA/Ser.L/V/II.) Doc. 43/15, 31 December 2015, para. 186.
}

Guatemala had the highest number of assassinations of indigenous activists per capita in the world. ${ }^{98}$ Despite the deadly risks, the indigenous resistance remains unabated. One activist told Amnesty International, "we defend the land with our blood." 99

\subsubsection{The Cockroach effect}

Besides the historic power players, the Guatemala state and, by extension, the process of democratisation is further challenged by the growing presence of violent non-state actors. Given the limitations of formal economic governance, informal economic governance has a disproportionately large role.

Indeed, the combination of weak formal political and economic governance is the perfect storm for international drug cartels. Due to weak formal political governance, cartels can carry out their illicit activities with impunity. Then, due to the weak formal economic governance, there is widespread poverty. This means there are countless youths "who have little hope of bettering their lives through education and steady employment." 100 According to the World Bank, sixty per cent of Guatemala lives under the poverty line. ${ }^{101}$

To make matters worse, Guatemala must contend with the 'cockroach effect'. This means that as a result of the policies of repression and interdiction in one place, cartels relocate to another area. For instance, the nationwide offensives against drug cartels in Colombia and Mexico, have led them to start using Central American

98 Yale Environment 360 (2019), 164 Activists Were Killed Defending Land and Water Last Year.

Available at: https://e360.yale.edu/digest/164-activistswere-killed-defending-land-and-water-last-year

${ }_{99}$ Amnesty International (2016), 'We are defending the land with our blood'. Defenders of the land, territory and environment in Honduras and Guatemala. Available at: https://www.amnesty.org/download/Documents/AMR014 5622016ENGLISH.PDF [accessed 7 November 2020].

100 Crisis Group Latin America (2011), p. 1

101 International Monetary Fund (2018), ‘Guatemala: More Investment and Social Spending Needed', Available at: https://www.imf.org/en/News/Articles/2018/05/30/NA0 60118-Guatemala-More-Investment-and-Social-SpendingNeeded [accessed 12 April 2020]. 
transit countries. ${ }^{102}$ Due to its location between the main producers of cocaine, Colombia, Peru and the Plurinational State of Bolivia, and the main cocaine consumer, the United States, Guatemala became a strategic point within international drug-trafficking. 103 The Zetas and other Mexican cartels traffic through Izabal on Guatemala's eastern border, through central Alta Verapaz, and through Petén in the north. They are battling for control of Huehuetenango, on the western border. In effect, there is a cartel presence on the eastern, western, and northern border. Yet, the cartels are not challenging the state but rather each other for control of Guatemala. ${ }^{104}$ From the perspective of statehood, it reveals the weakness of the formal security governance institutions: the state is unable to fully control the national territory.

The cockroach effect is not limited to drug-trafficking; it has led to other forms of violence. There is a link between the increased presence of the drug trade and the increasing levels of homicides. ${ }^{105}$ According to UNODC, Guatemala is plagued by the battles between cartels, organised criminal groups and law enforcement agencies. Coping with the onslaught of transnational crime is difficult even for a more robust state. In the case of Guatemala, a fragile state with a weak rule of law is now facing a mammoth security threat. 106 In addition, the extensive financial resources of the transnational cartels enable them to infiltrate the state, promoting their interests using the formal institutions of governance. ${ }^{107}$ For an emerging criminal elite, it provides an opportunity for profit. ${ }^{108}$ In contrast, for the majority, it is yet another source of suffering.

Nonetheless, despite the dangers, social resistance has risen in response to the threat of narco-trafficking and corruption. A notable case was in Santa Lucia Cotzumalguapa. Due to its location, it quickly became a hotspot for drug-trafficking between Guatemala and Mexico. A local social resistance emerged whose aim

102 Garzón, Juan Carlos and Bailey, John (2015),

'Displacement Effects of Supply-Reduction Policies in Latin America A Tipping Point in Cocaine Trafficking, 2006-2008', pp. 483, In: Brownstein, Henry (eds.) The Handbook of Drugs and Society. Available at:

http://fileserver.idpc.net/library/Displacement_Effects_of_S upply_Reduction\%20(1).pdf

103 UNODC (2011), Global Homicide Study 2011, United

Nations Office on Drugs and Crime. p. 3. Available at:

http://www.unodc. org/documents/data-and-

analysis/statistics/Homicide/Globa_study_on_homicide_

2011_web.pdf [accessed 24 April 2020]. was to "recover the community and local government from the hands of drug lords" and "promote economic and social development". ${ }^{109}$

The resistance movement defied informal actors of economic governance, like cartels, and formal institutions of economic governance, which prioritised elite interests. Furthermore, the activists were subjected to intimidation, harassment and extreme violence. By 2007, 11 leaders were assassinated. Yet, in court cases judges ruled in favour of the drug cartels. In economic policies, the institutions did not address widespread poverty. It was a rather blunt and "odious confirmation of the extent of corruption and state capture."110 Nevertheless, the local resistance has refused to accept the status quo.

Ultimately, economic governance is the backbone of any state. Tax policy determines the budget for public institutions and social programs. Moreover, in a country with a high rate of poverty, like Guatemala, the role of the state in reducing social inequalities is even more important. Nevertheless, it is evident that formal economic institutions are too weak and too captured to address many of the greatest economic challenges. The investment in poverty reduction is alarmingly low by regional standards. Then, there is the threat of informal economic actors, such as businesses and cartels, which seek to undermine the state. Through undue influence and corruption, they manage to override the common interests. However, there are spaces of resistance against both informal and formal economic actors. The leaders and individuals involved in these movements have paid dearly for their ideals. Yet, they have persisted, determined to create a more just world.

104 Crisis Group Latin America (2011), pp. 4-9

105 Garzón, Juan Carlos and Bailey, John (2016), p. 486

106 UNODC (2011), p. 53

107 Beyerle, Shaazka (2011), 'Civil Resistance and the Corruption-Violence Nexus,' The Journal of Sociology $\mathcal{E}$ Social

Welfare: Vol. 38 : Iss. 2 , Article 5., p55 Available at: https://scholarworks.wmich.edu/jssw/vol38/iss2/5 108 Gútierrez, Edgar (2016), p. 5

109 Beyerle (2011)

110 Ibid 


\section{CONCLUSION}

Twenty-four years ago, Guatemala underwent an important transformation. The Civil War ended and Peace Accords were signed. In the immediate aftermath, there was a great deal of optimism. There was a shared collective hope that a democratic order would be consolidated. In the years since, the results are more mixed. Guatemala is no longer ruled by a military dictatorship. There are no more massacres carried out silently in the mountains due to a state policy. However, it would be misleading to portray Guatemala as a peacetime state. The insecurity and violence which has been interwoven in its institutions remain very much a part of the national tapestry. In part, this is because the process of democratisation occurred within the context of a fragile, captured state. Guatemala gained its independence in 1821, almost two centuries ago. However, it would be misleading to portray Guatemala as a fully consolidated nation-state.

Colonisation was driven by a very racist ideology and a socioeconomic model rooted in the extreme exploitation of indigenous peoples. Within this context, independence implied the end of Spanish rule. It did not imply the end of the colonial model or the ideology which justified it. Thus, Guatemala emerged as an independent state 'freed' from the constraints of Spanish rule, but without ending the domination of a small elite. Over time, the nature of this elite has changed. Besides the original oligarchic elite, there is a military elite and emerging criminal groups. The Guatemalan state continues to serve the interests of the privileged few. In other words, the institutions which underpin formal governance have never been as powerful as the actors which determine informal governance. In many ways, Guatemala continues to be an informal Leviathan. The actors which define informal governance, such as businesses and cartels, manage to impose their interests with repression and impunity. In contrast, the actors which define formal governance trail behind. At times, formal institutions are captured by the informal actors of political and economic governance. In these cases, the state serves elite interests and not those of the public. In other cases, the formal institutions operate autonomously. Nevertheless, because of fragility, they are unable to fully implement the common good.

To make matters worse, Guatemala has gotten caught up in the larger geopolitical phenomenon of transnational drug trafficking, even though it is neither the main drug consumer nor the main drug producer. The drug trade has had the explosive effect of magnifying all the pre-existing social injustices and structural weaknesses. The weak political governance enables cartels to carry out their trade with impunity. The weak economic governance means there is a long line of desperately poor youths willing to enter the drug trade.

This all begs the question, where is the Guatemalan state headed? The Guatemalan state remains fragile and captured. Nevertheless, there has always been resistance against the status quo. Even during the darkest chapters of the colonial process, indigenous peoples were refusing to be assimilated by the emerging westernised culture. Even during the darkest chapters of the Civil War, there was a resistance unwilling to be silenced by the death squads. Even during the darkest moments of the drug-fuelled crisis, there is a resistance protesting the democratic erosions. Violence is interwoven throughout the history of Guatemala, but so are the dreams of a better world. Although only little by little, the country has moved in their direction.

\section{BIBLIOGRAPHY}

Albertson, Andrew and Moran, Ashely (2017), Untangling the Complexity of Fragile States. Available at:

http://trumancenter.org/wpcontent/uploads/2017/03/Untangling-the-Complexity-ofFragile-States.pdf [accessed 4 November 2020]

Alvarez, Enrique and Palencia Prado, Tania (2011), 'Guatemala's peace process: context, analysis and evaluation', In: Barnes, Catherine (eds.) Owning the Process. Public Participation in peace-making (Conciliation Resources: London)

Alvarez, Enrique and Palencia Prado, Tania (2011), 'Guatemala's peace process: context, analysis and evaluation', In: Barnes, Catherine (eds.) Owning the Process. Public Participation in peace-making (London: Conciliation Resources)

Arévalo, Bernardo (2013), Estado violento y ejército político: formación estatal y función militar en Guatemala (1524- 1963) (Guatemala: FyG Editores) p. 96

Bachmann, Olaf. 'Who Guards the Guardian: Seminar on the State, State Institutions and Governance of Security'. Lecture, King's College London, 8, February 2018 
Becker, Marc (2008), 'Third Continental Summit of Indigenous Peoples and Nationalities of Abya Yala: From Resistance to Power', Latin American and Caribbean Ethnic Studies, 3:1, 85-107, DOI: 10.1080/17442220701865879

Brett, R. (2017), 'The Role of Civil Society Actors in Peacemaking: The Case of Guatemala'. Journal of Peacebuilding $\mathcal{E}$ Development, 12(1), 49-64.

https://doi.org/10.1080/15423166.2017.1281756

Briscoe, Ivan (2009), 'A Criminal Bargain: The State and Security in Guatemala', Fundación Para Las Relaciones Internacionales Y El Diálogo Exterior (FRIDE), Madrid, 2009. V24

Bull, Benedicte (2014), 'Towards a Political Economy of Weak Institutions and Strong Elites', European Review of Latin American and Caribbean Studies, 97, pp. 117-28

Bull, Benedicte, Castellacci, Kashara, Yuri (2014), Business Groups and Transnational Capitalism in Central America: Economic and Political Strategies (New, York: Palgrave Macmillan)

Cabrera, Maynor and Schneider, Aaron (2013), 'Instituciones, Impuestos, y Desigualdad en Guatemala', Woodrow Wilson Center for the Americas. Available at:

https://www.wilsoncenter.org/sites/default/files/media/d ocuments/publication/Guatemala\%20V2.pdf

Casáus Arzú, Marta (2018), 'El racismo y su proyección actual: ¿un fenómeno nuevo o un problema sin resolver?', Cuadernos de Trabajo Social, 31(1), pp. 121-137

CICIG (2019), Guatemala: un Estado capturado. Available at: https://www.cicig.org/wpcontent/uploads/2019/08/Informe_Captura_Estado_2019.p df [accessed 2 April 2020]

COHA (2011), 'Guatemala's Crippled Peace Process: A Look Back on the 1996 Peace Accords', Council on Hemispheric Affairs, Available at: http://www.coha.org/guatemalascrippled-peace-process-a-look-back-on-the-1996-peaceaccords/ [accessed 8 April 2020]

Crisis Group Latin America (2011), ‘Guatemala: Drug Trafficking and Violence’ Report $N^{\circ} 39$. Available at: https:/ / d2071andvip0wj.cloudfront.net/39-guatemala-drugtrafficking-and-violence.pdf [accessed 14 April 2020]

Cruz, J.M. (2016), 'The State and the Reproduction of Violence in Post-Transition El Salvador and Guatemala', In: Ruzza, S.,
Jakobi, A., and Geisler, C. (eds.) Non-State Challenges in a Reordered World: The Jackals of Westphalia (London: Routledge) pp.157-174

Dixit A.K. (2008), 'Economic Governance'. In: Palgrave Macmillan (eds) The New Palgrave Dictionary of Economics. Palgrave Macmillan, London. https:/ / doi.org/10.1057/978-1349-95121-5_2611-1

Dudley, Steven (2018), 'Public security in private hands: the case of Guatemala's Carlos Vielman', Crime Law and Social Change 69, pp 519-531. Available at:

https://doi.org/10.1007/s10611-017-9762-7 [accessed 9 April 2020]

Figueroroa Ibarra, Carlos (2011), El recurso del miedo. Estado y terror en Guatemala. F\&G Editores: Guatemala City

Garzón, Juan Carlos and Bailey, John (2015), 'Displacement Effects of Supply-Reduction Policies in Latin America. A Tipping Point in Cocaine Trafficking, 2006-2008', In: Brownstein, Henry (eds.) The Handbook of Drugs and Society. Available at:

http:/ / fileserver.idpc.net/library/Displacement_Effects_of_S upply_Reduction\%20(1).pdf

Gútierrez, Edgar (2016), Guatemala elites and organized crime, Insight Crime. Available at:

https://www.insightcrime.org/wp-

content/uploads/2018/02/Guatemala_Elites_Organized_Cri me [accessed 6 April 2020]

Historical Clarification Commission (CEH) (1999), Guatemala: Memory of silence. Guatemala City: Historical Clarification Commission

Holden, Robert (2004), Armies without Nations: Public Violence and State Formation in Central America 1821-1960 (Oxford: Oxford University Press) pp. 26-130

Huntington, Samuel (1991), 'Democracy's Third Wave', Journal of Democracy 2(2), pp. 12-34. Available at: doi:10.1353/jod.1991.0016. [accessed 27 April 2020]

Icefi (2015), Política fiscal: expresión del poder de las élites centroamericanas. Instituto Centroamericano de Estudios Fiscales (eds.) Aguilar Umaña, Isabel. Available at:

http://icefi.org/sites/default/files/politica_fiscal_expresion _del_poder_de_las_elites_centroamericanas.pdf [accessed 13 April 2020] 
IDB (2006), The Politics of Policies. Economic and Social Progress in Latin America, 2006 Report. Inter-American Development Bank. Available at:

https://publications.iadb.org/en/publication/16950/politics -policies-economic-and-social-progress-latin-america-2006report [accessed 21 April 2020].

International Monetary Fund (2018), 'Guatemala: More Investment and Social Spending Needed'. Available at: https://www.imf.org/en/News/Articles/2018/05/30/NA0 60118-Guatemala-More-Investment-and-Social-SpendingNeeded [accessed 12 April 2020].

Kato, J. and Tanaka, S. (2019), Does taxation lose its role in contemporary democratisation? State revenue production revisited in the third wave of democratisation, European Journal of Political Research, 58: pp. 184-208. Available at: doi:10.1111/1475-6765.12276 [accessed 7 April 2020].

Kit, Wade (1990), 'The fall of Guatemalan dictator, Manuel Estrada Cabrera: US Pressure or national opposition?' Canadian Journal of Latin American and Caribbean Studies / Revue Canadienne Des études Latino-américaines Et Caraibes 15, no. 29 (1990): 105-27. www.jstor.org/stable/41799715 [accessed 4 November 2020]

Krause, Krystin (2016), 'The News Media and Public Support for Repressive Crime Control in Guatemala', Panoramas Scholarly Platform. Available at:

https://www.panoramas.pitt.edu/news-and-politics/newsmedia-and-public-support-repressive-crime-controlguatemala [accessed 17 April 2020].

Krznaric, R. (1999), 'Civil and Uncivil Actors in the Guatemalan Peace Process'. Bulletin of Latin American Research, 18(1), 1-16. Retrieved November 5, 2020, from http://www.jstor.org/stable/3339471

Oficina del Alto Comisionado de las Naciones Unidas (2019), Situación de las personas defensoras de derechos humanos en Guatemala: Entre el compromiso y la adversidad, pp.28-29. Available at:

https://www.refworld.org.es/docid/5ce489654.html [accessed 9 November 2020]

Palencia Prado, T. (1997), 'Advocates \& Guarantors: Establishing participative Democracy in Post War Guatemala', In; Sieder, R. and Wilson, R (eds.), Negotiating Rights (London: Conciliation Resources)
Pearce, Jenny (2018), 'Elites and Violence in Latin America Logics of the Fragmented Security State', Violence, Security, and Peace Working Papers. Available at:

http://www.lse.ac.uk/lacc/publications/PDFs/VSP1Pearce-Elites-Violence-Latin-America-web.pdf [accessed 14 April 2020]

Mann, M. (1986), 'The Autonomous Power of the State', In Hall, J.A. (ed.) States in History (Oxford: Blackwell) pp.109-136

Michel, James (2018), 'Managing Fragility and Promoting Resilience to Advance Peace, Security, and Sustainable Development' pp. 4-11, Center for Strategic and International Studies (CSIS). doi:10.2307/resrep22409. [accessed 4 November 2020]

Meade, Teresa A (2009), A History of Modern Latin America: 1800 to the Present. Chicester: John Wiley \& Sons

Rodríguez Quiroa, Luisa Fernanda (2018), 'Empresarios con poder: al menos 58 instancias del Estado en las que las cámaras tienen voto o voz', Plaza Pública. Available at: https://www.plazapublica.com.gt/content/empresarioscon-poder-58-instancias-del-estado-en-las-que-las-camarastienen-voz-y-voto [accessed 17 April 2020]

Rye, Tom, et al. (2018), The relationship between formal and informal institutions for governance of public transport, Journal of Transport Geography, Volume 69, pp.196-206, https:// doi.org/10.1016/j.jtrangeo.2018.04.025

Sanchez-Ancochea, D. (Ed.), Martí i Puig, S. (Ed.). (2014). Handbook of Central American Governance. London: Routledge, p149-163

Sanchez, Omar (2009), 'Tax Reform Paralysis in Post-Conflict Guatemala,' New Political Economy, 14:1, pp. 101-131, Available at: DOI: 10.1080/13563460802673325 [Accessed 2 April 2020].

Schultze-Kraft, M., Chinchilla, F.A. \& Moriconi, M. (2018), 'New perspectives on crime, violence and insecurity in Latin America', Crime Law Soc Change 69, pp. 465-473. Available at: https://doi.org/10.1007/s10611-017-9758-3

Streeter, Stephen (2000), Managing the Counterrevolution: The United States and Guatemala, 1954-1961. Athens: Center for international studies, p12

UNODC (2011), Global Homicide Study 2011. United Nations Office on Drugs and Crime. Available at: http://www.unodc. org/documents/data-and- 
analysis/statistics/Homicide/Globa_study_on_homicide_ 2011_web.pdf [accessed 28 April 2020]

Weber, Max (1919), Politik als Beruf, München und Leipzig. Verlag von Duncker \& Humblot

Webre, Stephen (2019), 'Guatemala (Colonial Period)'. Oxford Bibliographies in Latin American Studies. Available at: doi:10.1093/obo/9780199766581-0209

World Bank (2020), Guatemala Overview. Available at: https://www.worldbank.org/en/country/guatemala/overv iew 